\title{
Sezai Karakoç’un Fikrî Yazılarında Doğu ve Batı Medeniyeti Tasavvuru
}

\section{Ahmet KOÇAK ${ }^{1}$}

\begin{abstract}
Özet
İnanç ve ahlâk nizamı olarak bir milletin ve toplumun maddî ve manevî varlığına ait üstün niteliklerini, değerlerini, fikir ve sanat hayatındaki çalışmalarını, ilim, teknik, sanayi alanlardaki gelişmelerini ifade etmek üzere kullanılan medeniyet kavramının kökeni İslâm dünyasında hicrete kadar götürülebilir. Hicretle Yesrib şehrinin adı Medine şeklinde değiştirilmiş ve burası yeni bir sistemin, anlayışın merkezi olmuştur. Daha sonraki yüzylllarda İbn-i Haldun, Mukaddime'sinde toplumların hayatını ifade ederken bu kavramdan bahseder. Batı'da ise on sekizinci yüzyılın ortalarında kendi toplumlarının teknik ve ekonomik anlamda gelişmişliğini ifade etmek üzere ilk defa Fransızca olarak "civilisation" kavramı kullanılır. Osmanlı'da medeniyet kavramı ise, Batı'daki civilisation kavramına karşılık olarak ve Batı’nın teknik anlamda üstünlügünü ifade etmek üzere üretilir. Dolayısıyla Türk edebiyatında on dokuzuncu yüzyılda en çok kullanılan kavramlardan birisi “medeniyet”tir. Bugüne kadar birçok Türk fikir adamı, aydını bu kavramı tanımlamaya çalışmış, onun üzerine fikir yürütmüştür. Şüphesiz bu büyük düşünürlerden birisi de son yarım asra damgasını vuran, şair ve fikir insanı Sezai Karakoç'tur. Karakoç'a göre medeniyet temelde tektir ve bu meşale ilk insandan bugüne kadar elden ele taşınarak gelmiștir. $\mathrm{O}$, vahiy temelli bu anlayıșın hepsine birden "Hakikat medeniyeti" adını verir. Karakoç, fikrî yazılarında "hakikat medeniyeti", "İslâm medeniyeti" ya da "insanlığın medeniyeti" gibi kavramları ilk insandan başlayarak son peygambere kadar takip eden silsilede oluşan medeniyeti ifade etmek üzere kullanır. Onun medeniyet anlayışı, genelde sınıflandırıldığı gibi Doğu-Batı medeniyeti şeklinde ikiye ayırmak yerine, üçüncü bir kategori olarak İslâm medeniyetini ayrı bir başlık altında ele almasıdır. Bu tasnifiyle onun medeniyet kavramına yüklediği anlam oldukça farklı ve yenidir. Sezai Karakoç, Batı medeniyetini de Eski Yunan medeniyetinden başlatarak bir bütün olarak kabul eder. Eski Yunan'dan Roma'ya oradan Rönesans ve Reforma uzanan süreçte Batı medeniyetinin geçirdiği evreleri farklı açılardan yorumlayan Karakoç, Batı medeniyeti üzerine yeni dikkatler sunar. Batı'nın özellikle son iki yüzyılda medeniyet görüntüsü altında Asyalıyı, Afrikalııı kısaca kendinden olmayanı kendisine dönüştürme hedefinin altında yatan nedenleri açılığa kavuşturmaya çalışır. Bu makale çerçevesinde şair ve mütefekkir Sezai Karakoç’un fikrî yazılarında en çok üzerinde durduğu kavramlardan birisi olan, genelde "medeniyet” özelde ise Doğu ve Batı medeniyetleri kavramlarıyla ilgili düşünceler üzerinde durulmuştur.
\end{abstract}

Anahtar Kelimeler: Sezai Karakoç, medeniyet, Doğu, Batı, İslâm medeniyeti.

\section{The Idea of Eastern \& Western Civilizations in The Writings of Sezai Karakoç}

\begin{abstract}
Origin of the concept of civilization which is used for expression of a nation's ethic and belief system, values, literary and artistic works, and scientific, technological and industrial developments can be rooted in the emigration in Islamic world. After the emigration, city of Yesrib has been renamed as "Medine" and became the center of a new system and understanding. During the following centuries, İbn Khaldun mentions this concept as talks about lives of societies. On the other hand, in West, "civilization" is used to express high-level technological and economical
\end{abstract}

Yrd. Doç. Dr., İstanbul Medeniyet Üniversitesi, Fen Edebiyat Fakültesi, Türk Dili ve Edebiyatı Bölümü, kocakahmet7o@hotmail.com 
development of their communities, at first in French. The word "medeniyet" is lexicalised by Ottomans to be corresponding to "civilisation", and is used to express technological supremacy of West. Attendantly, "medeniyet" is one of the most commonly used concepts in Turkish literature during nineteenth century. Since then, numerous Turkish intellectualists have tried to define and explain it. One of these great thinkers is Sezai Karakoç who leaves his mark on the last halfcentury as a poet and an intellectualist. According to Karakoç, civilisation is unique and has been carried like a torch since Adam until today. He calls this apocalyptic approach as "Hakikat medeniyeti" (Civilization of Truth). In his articles, Karakoç mentions some statements like "hakikat medeniyeti", "İslam medeniyeti", "insanlığın medeniyeti" (civilization of humanity) in the meaning of the civilization which is built from the time of primitive men to the age of last prophet, Muhammed. His conception of civilization differs from the usual way of thinking that separates civilization into Eastern and Western. Alternatively, he suggests a third category: "Islam civilization". Sezai Karakoç considers Western civilization as a whole matter which is starting from the Ancient Greek. He suggests some new opinions on different periods of Western civilization such as Ancient Greek, Rome, Renaissance and Reform. He also tries to shed some light on the underlying reasons of Western politics which aim to assimilate Asian, African and all other cultures in the name of civilization. This article will focus on the concepts of "civilization", "Eastern civilization" and "Western civilization" in writings of Sezai Karakoç.

Key words: Sezai Karakoç, civilization, East, West, Islam Civilization.

\section{Medeniyet Kavramı}

Bir milletin maddî, manevî varlığına ait üstün değerlerden, fikir ve sanat hayatındaki çalışmalardan, ilim, teknik, sanayi, ticaret vb. alanlardaki gelişmelerden yararlanarak ulaştığı refah, rahatlık ve güvenlik içindeki hayat tarzı, yaşama biçimi şeklinde tarif edilebilecek olan medeniyetin İslâm dünyasında kullanımı Grek kültüründen çeviri faaliyetlerinin gerçekleştiği sekizinci yüzylla kadar dayanmaktadır (Kutluer 2000: 297-297). İslâm dünyasında medeniyet ile akraba kelimelerden ilki İslâm Devleti'nin kuruluşunu ilan eden Medine şehridir. Bu şehirden olanlara 'medenî' denirken, herhangi başka bir şehirde ikamet edene de 'medînî' denilmiştir. Medînî olmayanlara yani göçebelere de 'bedevî' adı verilmiştir (Uludağ 2003: 22). Nitekim İbn Haldun toplumların gelişmelerini 'Umran' kavramıyla açıklamıştır (Bilge 2006: 234-244).

$\mathrm{Bu}$ kavramın Batı'daki serüveni ise çok daha sonraki asırlardadır. Avrupalı toplumların üstünlük iddialarını ifade etmek maksadıyla XVIII. yüzyılın ikinci yarısından itibaren kullandıkları Fransızca "civilisation" (Görgün 2000: 298)2, Fransa ve İngiltere'de seçkin zümrenin hayat tarzını ifade etmek üzere kullanılmıştır. Bu kavram, "medenîleşmiş / civilized” kelimesinin zıttı olan 'vahşi / savage'e karşı Avrupa medeniyetinin üstünlügünü göstermek için kullanılmıştır (Güler 2006: 14).

Medeniyetin Osmanlı Türkçesine geçişi ise, Fransızcadaki "civilisation"a karşılık olarak Arapça (m-d-n) "şehir" anlamina gelen "medîne"den türetilen ve Türkçeye özgü "medeniyet”tir (Baykara 2007: 33-55). Arapça'da "medeniyet" karşılığı olarak kullanılan "ettemeddün" de yine aynı kökten gelmektedir. Dolayısıyla temeddün veya Türkçede kullanıldığı şekli ile 'medeniyet' şehir halkının yaşayışını benimsemek ve şehirleşmek anlamına gelmektedir (Uludağ 2003: 22-30). Nitekim Batı dillerinde "medeniyet" in karşılığ olan "civilisation" da Latince'de "şehirli" anlamına gelen "civilis" kelimesinden türemiştir (Kutluer 2000: 296) 
Türkçeye on dokuzuncu yüzyılda Batı'dan geçen "civilisation”u ilk kez Mustafa Reşit Paşa (Meriç 1983: 236; Okay 1991: 19-20)3, yine bu yüzyllda ona karşllı olarak türetilen "medeniyet" kelimesini ise Sadık Rifat Pașa kullanır (Baykara 2007: 54)4. Medeniyetin yanında "belli yasalara uyarak şehirde yaşayan halk" anlamında uygurdan "uygarlık", "bayındırlık ve mamurluk anlamındaki "umran" (Ayverdi 2005: 3237) da medeniyeti ifade etmek üzere kullanılan kavramlardır. Uzun zaman medeniyet karşllı̆gl olarak "umran", "hadariyyet" ve "uygarlık" gibi kelimeler kullanılmıştır (Gökalp 1970: 30).

On dokuzuncu asrın temel kavramlarından birisi olan medeniyetin bir inanç ve ahlâk nizamına dayandığı gibi, toplumda meydana gelen teknik ilerleme (Ayverdi 2005:1974), ilmî derinlik, fikrî zenginlik, iktisadî gelişmişlik, ruhî nezaket, fertlerin birbirine karşı saygı ve sevgi beslemesi, insanın fikirce, ahlâkça ve ruhça yükselmesi (Meriç 1986: 43), akla, araştırmaya ve disiplinli bir çalışma hayatına önem verilmesi, hukukun ve insan haklarının üstün bir değer olarak kabul edilmesi şeklinde geniş bir tarifi yapılabilir (Baykara 2007: 4555; Baykara 1982: 12-17). Ahmet Hamdi Tanpınar, "Tanzimat devrinin ilk ideolojisi medeniyetçiliktir” tespitini yaptıktan sonra, Sadık Rıfat Paşa'dan itibaren Cevdet Paşa, Münif Paşa gibi önemli devlet ve fikir adamlarının bu kavramın tarifini yapmaya çalıștıklarını, hatta Şinasi'de bunun kendi ve daha sonraki nesli için bir "din haline" geldiğine işaret eder (Tanpinar 2007: 147).

Avrupa'ya ilk defa elçi olarak giden Yirmi Sekiz Çelebi Mehmet'ten, Sadık Rıfat Paşa'ya, Mustafa Sami Efendi'den Ahmet Midhat Efendi'ye ve Ahmet İhsan'a kadar Avrupa hakkında düşüncelerini aktaran Osmanlı aydınında şu ya da bu şekilde Batı medeniyetine karşı büyük bir hayranlık vardır (Uçman 2010: 617-620). Buna karşılık Batı medeniyetinin teknik anlamda gelişmeler gösterdiğinin farkında olan, ancak bu medeniyete mesafeli duran, hatta bu noktada yeni bir medeniyet tasavvuru geliştiren büyük fikir adamları da eksik olmamıştır. $\mathrm{Bu}$ isimlerden birisi de Sezai Karakoç'tur.

\section{Sezai Karakoç’ta Medeniyet Kavramı}

Osmanlı aydınının büyük bir kısmının hayranlık duyduğu Batı medeniyetine karşı gür sesi çıan isimlerin başında Mehmet Akif ve onun devamında Necip Fazıl gelir. Bu çizgiyi devam ettiren ve yeni bir medeniyet tasavvuru kuran isim, son yarım asrın büyük şairi, mütefekkiri ve sanat insanı Sezai Karakoç’tur. Cemal Süreya'nın “Bulgucu adam. Belki de ülkemizde tek bulgucu. Çok daha yetenekli bir Mehmet Akif'in tinsel görüntüsüyle adamakıllı dürüst bir Necip Fazıl'ınkini iç içe geçirin, yaklaşık bir Sezai Karakoç fotoğrafı elde edebilirisiniz." (Süreya: 2004:278) dediği Sezai Karakoç'un fikri yazılarındaki temel kavramlardan birisi medeniyettir. $\mathrm{O}$, insan hayatını bütüncül olarak kuşatan bir kavram olarak gördüğü medeniyetin iki yönü olduğundan bahseder. Bunlardan ilki medeniyet kavramının tanımı itibariyle zaman içinde "bütün insanlığa hitap eden tarih olgusu"dur (Karakoç 2005:7). Medeniyetin bu boyutu "Illk insandan başlayıp bugüne kadar gelen ve bundan sonra da insanlığın sonuna kadar sürecek olan”, yani tüm zamanı kuşatan bir olgudur (Karakoç 1999:237). Medeniyetin ikinci boyutu ise, "insanın sadece fiziki ya da fizyolojik ihtiyaçlarına cevap veren bir sistem olmakla kalmaz, aynı zamanda manevî-ahlâkî, metafizik ve kültürel isteklerini de karşılamak amacını taşır.” (Karakoç 2005:7).

3 “Civilisation” kelimesinin dilimize Mustafa Reşit Paşa tarafından girdiğini aktaran Meriç, onun Paris’ten 1834 yılında gönderdiği resmî yazılarında Türkçeye "terbiye-i nas ve icra-yı nizamat [insanların eğitimi ve düzenin uygulanması] olarak tarif ettiğinden bahseder. Viyana elçisi Sadık Rıfat ise Frenklerin “civilisation” kelimesini “usul-i me’nusiyet” [alışkanlıklar düzeni] şeklinde tanıtmıştır ki bu kelime daha sonra "medeniyet” ile karşlanacaktır. Orhan Okay ise Islahat Fermanında Batılı devletler hakkında "milel-i mütemeddine (medenî milletler) ifadesinin kullanılmasına dikkat çektikten sonra Şinasi’nin Tanzimat Fermanı'nı ilan eden Mustafa Reşit Paşa için “Sensin ol fahr-i cihan-ı medeniyyet” dediğini aktarır.

4 "Civilisation”a karşılık olarak düşünülen medeniyet kelimesi ilk defa 1838 yılında Sadık Rıfat Paşa tarafından kullanılmıştır. 
The Idea of Eastern \& Western Civilizations in The Writings of Sezai Karakoç / A. Koçak (p. 51-63)

Düşünce ve edebiyat tarihimizde medeniyet kavramını sisteminize eden, hatta "İslâm medeniyeti” fikrinden ilk bahseden Sezai Karakoç'tur (Kaplan 2008: 222). Dolayısıyla Karakoç, medeniyetin teorisini kurarak bu anlayışta yeni bir yol açmıştır. Daha önce ister Batı ister Doğu medeniyeti olsun, bundan bahsedenlerin kastettikleri şey, modernleşme ya da Batı medeniyetine karşılık bulma çabalarıdır. Sezai Karakoç, modernlikle ya da Modern Batı tecrübesiyle kastedilen medeniyet olmadığını fark eden ilk düşünür olarak ifade edilir (Kaplan 2008: 224).

Karakoç'a göre medeniyet kavramı kültürü de içine alan bir kavramdır. Dolayısıyla Ziya Gökalp’in kültür tanımlamasından ayrılır. Çünkü Gökalp’e göre kültür millî, medeniyet beynelmileldir. Medeniyet bir grup ulusun ortaya koyduğu ortak eserlerdir. Oysa Karakoç, her medeniyete bir kültür tekabül ettiğini savunur. Karakoç'a göre İslâm medeniyeti diyorsak, bir de İslâm kültüründen bahsetmek lazımdır (Baş 2008: 222).

Temelde tek bir medeniyet olduğunu söyleyen Karakoç, onun da ilk insan Hz. Adem'den itibaren kurulan, yaşamış somut medeniyetler olduğunu söyler (Karakoç 1999: 237). Karakoç'a göre "medeniyet” kelimesi bir terminoloji ve kavram karışıklığına yol açtığı için düşünürleri de yanılgıya sevk etmiştir. Ona göre, biri tüm insanlığa hitap eden, diğeri ise tarih terimi olarak, tarihte somut olarak adlandırılmış medeniyetler vardır. Başlangıçtan bugüne kadar insanlık için tek bir medeniyet olduğu düşünülürse, medeniyetlerin hepsi bu medeniyetin parçalarıdır. Karakoç'un "Medeniyet" dediği bir "medeniyet ideali" olmaktadır. Diğerleri bu ideali ararken uzun vadede gerçekleşen "reel medeniyetlerdir." (Karakoç 1999: 237-238) Medeniyeti bölüm bölüm düşünüp, adını ve sayısını çoğaltmak da mümkündür. Ancak medeniyeti tüm insanlığın malı sayıp bir bütün olarak tek medeniyet saymak da mümkündür (Karakoç 1986: 56).

Aslında tek olan çoğul olarak bahsedilen medeniyetler tarih içinde dallara ayrılmış, kimisi sönmüş ya da sönmeye yüz tutmuş, ancak tekrar tekrar dirilenler de olmuştur (Karakoç 2005: 17).

Karakoç'a göre medeniyetlerin ömrü, onların doğuş ve çıkışlarında gizlidir. İddialı ve sağlam temele dayanan medeniyetlerin ömrü de uzun olur. Medeniyetin temel ögeleri insanlığın ihtiyacına ne kadar cevap vermekte güçlü ise, yaşaması da o derece uzun sürer (Karakoç 1986: 248-249). Toynbee gibi medeniyetlerin tıpkı insan gibi doğup, büyüyüp, öldüklerini söyleyen düşünürler de vardır. $\mathrm{Bu}$ düşünüre göre günümüze kadar yirmi altı medeniyet kurulmuş, bunların bir kısmı ömrünü tamamlamış, yok olmuş, bir kısmı ise erken ölmüş yani dondurulmuş medeniyetlerdir ki, Osmanl medeniyeti bu dondurulmuş medeniyetler sınıfındadır. Bu görüşün karşısında olanlar da vardır (Karakoç 1986: 235).

Medeniyetlerin zaman içinde birbirinden etkilenmesini olağan karşılayan Karakoç, tarih içinde medeniyetlerin birbirinden bazı alış verişlerde bulunabileceğini söyler. Ancak o her medeniyette hâkim bir duygu olabileceğini belirtir. Örneğin, Mısır medeniyetinde hâkim olan duygu "korku"dur. Bunun için onlar devasa binalara, ehramlara yönelmişlerdir (Baş 2008: 226). Mezopotamya medeniyetinde temel duygu "hayranlık”tır. Gök güzelliği ve düzeni hayranlıkta erime duygusu oluşturur (Karakoç 1977: 63). Roma medeniyetinde ise, "hâkim olma" duygusu esastır. Ona göre Roma, insan gücüyle yine insanları hegemonyası altına alma davasında olmuştur. Roma'nın devamı olan yeni Batı medeniyeti ise, maddenin gücüyle eşyayı, evreni ve insanı hâkimiyeti altına almaya çalışmaktadır. Eski Yunan medeniyetinde sanat duygusu, yani estetik hâkimken, yeni dönemde bu duygu şuuraltından bir etki aleti olmuştur. Modern Batı anlayışının da en çok ilgilendiği şey, etkileme duygusudur (Baş 2008: 227).

Mezopotamya, Mısır ve Grek medeniyetleri belli noktalarda öne çıtığı için, ne kadar sürerse sürsün yıkılmaya mahkûm olmuşlardır. Mezopotamya ve Mısır medeniyetleri karaya, nehre ve göğe fazla şartlanmış medeniyetlerdir. Ziraat, geometri ve astronomiye dayanan bir medeniyettir. "Güneş sisteminden öteye gidemeyen bir dünya anlayışı"na sahiptir. Realist bir hayat görüşü ve metafizik yoksulu bir anlayışın hâkim olması dolayısıyla bu toplumlarda 
sanat güçlüdür, coğrafi bilimler gelişmiştir. "Yönetim göklerin iradesiyle olup biter." Bunun sonucunda Firavun ilahlaşmıştır. Hâlbuki Yunan medeniyetinde yönetim insanların iradesi dâhilindedir. Tek tanrı inancı karşısında bütün bu medeniyetler yok olmaya mahkûmdur ve nitekim öyle olmuşlardır.

Sezai Karakoç’un medeniyet kavramına yaklașımında önemli bir faktör de onun "millet" kavramıyla "medeniyet"i aynı daire içinde düşünmesidir. Millet kavramının Kur'an'da aynen geçtiğini belirten Karakoç, son yüzyılda Avrupa'da oluşan "nation" olgusuyla bunu sınırlandırdıklarını, bunun da sağlam bir dayanağının olmadığını söyler. Çünkü bu düşüncedeki millet kavramı ırka, dile dayanır. Hâlbuki İslâm milleti "aynı inancı paylaşan insanların şuurlu topluluğu"ndan oluşur. Bu yönüyle millet, medeniyete bağlı bir kavramdır (Karakoç 1986: 172).

"Ak ve Kara” başlıklı bir makalesinde Karakoç, insanlığın var oluşundan beri iyinin ve kötünün çarpıştığını söyler. "Doğru ile iyinin, güzel ile çirkinin medeniyetleri” ifadelerini kullanan Karakoç, bu iki medeniyeti "bal ile zehir, inci ile karataş, sülün ile yılan, kartal ile karga, altınböceği ile akrebin ayrılmasından, çarpışmasından doğan iki medeniyet” sözleriyle tanımlar. Karakoç, bu iki anlayışı "Ak medeniyet ile kara medeniyet" (Karakoç 1996: 59) olarak niteler.

Yazara göre medeniyetin referans noktası vahiydir (Karakoç 2009a:36). Medeniyet, insanın ne olduğunu, ne yapması ve yapacağı şeyi nasıl yapması gerektiğini ortaya koyan bir temel dayanaktır. Karakoç'a göre vahyin dünyada somut olarak ortaya çıkmış şekli medeniyettir (Karakoç 2005:11). Bu özelliklerinden dolayıdır ki medeniyet "Hayatımızın her safhasında, duygularımız, düşüncelerimiz ve davranışlarımızla karşılaştığımız bütüncül bir olaydır. Yani, her an, her hareketimiz medeniyetle ölçülür, medeniyetle tartılır ve medeniyetle değerlendirilir. Onunla değiştirilir, onunla değer kazanır. Düşüncelerimiz, duygularımız, eserlerimiz, hayatımız, hayat tarzımız, ahlâkımız, hepsi medeniyet hadisesine dâhildir." (Karakoç 2003b:134-136).

\section{Doğu, Batı ve İslâm Medeniyetleri}

Sezai Karakoç, günümüzdeki ana medeniyetleri tanımlarken yaygın olan ikili anlayışın aksine, medeniyetleri üçe ayırmaktadır. Literatürde genel olarak karşımıza Doğu ve Batı medeniyeti olarak iki medeniyet çımaktadır (Karaca 2015: 394). Ancak, aralarındaki temel farklılıkları göz önünde bulunduran Karakoç, Batı ve Doğu medeniyetlerinin yanında İslâm medeniyetini Doğu'dan ayrı bir medeniyet olarak değerlendirir ve medeniyetleri üç başlığa ayırır.

Batıyla kastedilen, temelde Avrupa ve son yüzylla birlikte Amerika Birleşik Devletleri'nin temsil ettiği medeniyettir. Doğu ise, Çin ve Hint gibi antik temellere dayanan medeniyeti temsil etmektedir. Sezai Karakoç'a göre bu iki medeniyetin dışında ve onların üstünde olan İslâm ise, ne Doğu'dur ne Batı'dır. Doğu'nun karakterine işlemiş olan mutlak mistisizm ifratından da Batı'nın mizacını oluşturan mutlak maddeci tefritinden de ayrı tutulması gereken madde ile ruhun denge noktasıdır. Karakoç, kendisini "mutlaka doğulu" ya da günümüzde "birçoklarının gereksiz olarak yaptığı gibi batılı" saymaz (Karakoç 2009c:2123).

\section{Doğu/Doğu Medeniyeti}

Karakoç'un Doğu'yla kastettiği bütün bir Asya'dır. Kur'an-ı Kerim'de Rum suresinde işaret edildiği gibi İslâmiyet’in geldiği dönemde Batı'yı Bizans, Doğu'yu da İran temsil etmektedir. Ancak İslâm güneşi Doğu'da doğmasına rağmen Karakoç'un kastettiği Doğu kavramı coğrafi bir tanımlamayı değil, müstakil olarak "İslâm medeniyeti", ya da "Hakikat medeniyeti"ni tanımlar. Dolayısıyla İslâm, ne Doğu ne de Batı'dır (Karakoç 1975: 399). Karakoç Doğu ile kastedilenin İslâm olmadığını özellikle vurgular: "İslâm ne Doğu ne de Batı'dır, Orta'dadır. $\mathrm{Bu}$ da pek çok Batılı bilim adamı tarafından fark edilmemekte ve Doğu ile İslâm 
özdeşleştirilmektedir. İslâm'ı herhangi bir Doğu sistemi olarak görmektedirler.” (Karakoç 1997b:95). Onun düşünce dünyasında öncelik Doğu'yu bilmektir. Kendini bilmenin aşamalarından biri Doğu'yu bilmekle başlar. Doğu-Batı çizgisi arasında kesin bir çizgi olduğuna inanan Karakoç, "Asyalı Asyalıdır, Avrupalı Avrupalıdır” düşüncesindedir.(Karakoç 1980:331) Doğu ruhu, mistik bir şekilde bütüncüdür (Karakoç 1986:126). Doğu karşısında olanı bütün olarak kavrar. Doğu'da esas olan “değişmeden kalabilmektir.”

Doğu kavramından farklı olarak tarihte peygamberlerin gönderildiği ve medeniyetlerin kurulduğu bölge olarak Orta Doğu'yu kullanan Karakoç, insanlığın dirilişinin Orta Doğu'nun dirilişiyle doğru, Avrupa'nın dirilişiyle ters orantılı olduğunu söyler. (Karakoç 1996: 50).

Batı'da ve Doğu'da insanoğluna yapılan zulümlere karşı, insanlığın kurtuluşu için büyük hamlelerin hepsinin Orta Doğu'da gerçekleştiğine işaret eden Karakoç, (bu arada o Ortadoğu yerine İslâm ülkesi demeyi uygun bulur) Islam medeniyetinin inşasında önemli vazife üstlenen bazı peygamberleri örnek verir. Hz. Nuh insanlığın yeniden ihyasını sağlamıştır. Hz. İbrahim Babil ve Mısır'da hükümdarlara ve putlara karşı savaş başlatıış, Hz. Yusuf Mısır'a hakikat, adalet ve gerçek inanç götürmüş, Hz. Musa firavunun zulmüne başkaldırmış, Hz. Yahya ve İsa insanlığı uyarmışlardır. Nihayet en büyük peygamber aracılığıyla İslâm'ın gelişi, yaşayışı, devlet kuruluşu Orta Doğu'da gerçekleşmiştir (Karakoç 1996: 50). Onun için Ortadoğu, bir medeniyet ocağıdır (Karakoç 1998: 76).

Hz. Adem'den son peygambere kadarki peygamberler medeniyetin öncüleri, kurucuları ve rehberleridir. Hz. Adem'in cennetten yer yüzüne iniși dirilișin başlangıcıdır. İnsanlığın ikinci atası saylan Hz. Nuh ve onun gemisi, medeniyetin protoplazmasını taşır. Hz. İbrahim'in hayatı "hakikat medeniyetini yaşatıcı özlerin sembollerini toplayan kutlu bir dergidir." Kabe'nin yapılışı, toplumun ve milletin her yönden bütünleniş çağıdır. Hz. İbrahim'in insanlığı hayvanlık derekesine düşürmekten tekrar kurtardığını ifade eden Karakoç, onun insanlık uygarlığını, mucize uygarlığını tekrar "İslâm milleti" katına yükselttiğini söyler. Peygamberlerin hayatı baştan aşağı bir medeniyet inşa etmiştir. İslâm toplumu, $\mathrm{Hz}$. İbrahim'in kurduğu hakikat medeniyetinin devlet gelişimini Hz. Yusuf gerçekleştirmiş̧tir. Ancak esas İslam medeniyetinin teşekkülü "cennetin ta kendisi" olarak ifade edilen son peygamberle gerçekleşmiştir.

İki yüzyıldır hep Avrupa’ya bakmanın sonunun geldiğine işaret eden Karakoç, “Artık Asya’ya dönüp bakmanın sırası geldi.” der. Asyalı olduğumuzu bile söylemekten çekinir duruma geldiğimizden yakınan Karakoç, bu yüzyılın “Asya ve Afrika Aksiyonu” olacağını söyler. Asya ve Afrika'da doğan yeni medeniyete, Anadolu medeniyetinin "yeni bir sütun eklemeli, bir pencere açmall, bir kubbe ve bir minare armağan etmeli”dir ki, Asya'ya armağan edilen bu kubbeden "Hakikat" çağrılsın, ifadelerini kullanır (Karakoç 1997a: 105).

\section{Batı / Batı Medeniyeti}

Sezai Karakoç Batı'yı Avrupa'nın merkezini oluşturduğu bir bütün olarak almaktadır. Onun Batı tanımlaması coğrafi bir sınır çizmekten ziyade Batıyı aynı değerler sistemi içinde bir bütün olarak tanımlama şeklindedir. Bu bağlamda Avrupa sınırları içine girmeyen Amerika, İsrail ve Rusya'yı Batı'nın bir parçası ya da bütünün cüzleri sayar. Karakoç'a göre bugünkü Modern Batı medeniyeti, "Grek medeniyetinin hazanında bir Roma, Roma'nın bağ bozumunda bir Hristiyanlık, Ortaçă̆’ın gün batımında bir Rönesans, Rönesans'ın altın noktasında bir Reform, Reformun arkasından Aklın diktatörlüğü̈dür (Karakoç 2000:37-38). Batı medeniyeti kökleri M.Ö. 120o'lü yıllara uzanan Eski Yunan medeniyetine dayanır. Büyük İskender’in fetihleriyle Anadolu, İran, Mezopotamya ve Mısır gibi eski çă̆ medeniyetleriyle tanışan ve kaynaşan Klasik Yunan medeniyeti geniş coğrafyalara yayılmıştır. Roma Devleti'nin genişlemesiyle yeni sentezler ortaya çıkmıştır. Paganizme dayalı çok tanrılı dinlerin yaygın olduğu bu ortamda Hristiyanlık zuhur etmiştir. Tek tanrılı bir din olan Hristiyanlık inancına Batı insanı tam bir gönül rızasıyla teslim olmamış, onun otoritesi karşısında aciz kaldığı için Hristiyanlığa yönelmiştir (Binici 2012: 97). "Bu yüzden de 
Sezai Karakoç’un Fikrî Yazılarında Doğu ve Batı Medeniyeti Tasavvuru / A. Koçak (51-63. s.)

Roma'dan Hristiyanlığa ne katmak gerekse ve mümkünse katmış, Hristiyanlığı kendine uydurmaya" gayret etmiştir (Karakoç 1987: 26).

Roma medeniyeti’nin Hristiyanlıkla birleşmesinin "Hakikat Yolu'nun lehine olmadı" ğını söyler. Bu birleşme (sentez) sonucunda ortaya "trajik, ilahlaşmış, yani yarı ilah, yarı insan bir varlık” olan bir Hz. İsa portresi çıkmıştır. Hristiyanlık, anlayış ve pratik olarak bir yandan tahrif edilirken, diğer yandan yayılmaya devam etmiştir. Ancak, "Hristiyanlık kendi başına bir medeniyet olamadı. Değişikliğe uğrayarak Grekoromen medeniyeti’nin bir unsuru durumunda kaldı.” (Karakoç 2005:19-22).

Batı'da Ortaçağ’a gelindiğinde ise, Eski Yunan kültürü giderek zayıflamaya başlamış, kiliseye karşı güven iyice azalmıştır. Böyle bir ortamda doğan Rönesans ve Reform hareketleri Eski Yunan kültürünün yeni bir yorumla tekrar gün yüzüne çıkarılmasıyla sonuçlanmıştır. Kiliseye karşı bir tepki olarak ortaya çıkan bu hareketler neticesinde tahrif edilmiş Hristiyanlık inancını insanın hayatından çıkarmış, yerine maddeyi yerleştirmiştir. Bu yeni anlayış, Fransız İhtilali, Sanayi Devrimi ve Teknoloji Devrimi süreçlerini beraberinde getirerek bugünkü Batı medeniyetinin tanziminde temel taş olmuștur. Batı'nın Rönesans'ı gerçekleștirmesinde İslâm medeniyetinin Endülüs yoluyla Batıya taşınmasının rolü büyüktür. Avrupa eski Yunan medeniyetinin kazanımlarını bu yolla tekrar elde etmiştir (Karakoç 1977: 35). "Rönesans dışa dönük bir meraktan doğdu.” diyen Karakoç, Hristiyan dünyasının Müslümanların üstün yanlarını ve geçmişe ait medeniyetleri keşfetme yolunda büyük seyahatlere çıktıklarını ve bunun neticesinde oralarda gördükleri yeni şeyleri kendi bünyelerine kattıklarını ifade eder (Karakoç 1996: 70). Ona göre Rönesans, Hristiyanlığın İslâm’a karşı kendini savunmak için Batı medeniyetini imdada çağırmasıdır (Karakoç 1987: 23; Bayraktar 2008: 284).

Karakoç'a göre Ortaçağ sonrası Batı'nın oluşumu üç ana alanda ortaya çıkan değişimin neticesinde olmuştur. Bunlardan ilki sanat, ikincisi düşünce ve bunların yansımasıyla düşüncedeki değişimdir. Şair, yazar, ressam ve heykeltıraşlar ortaya koyduklarıyla "Ortaçağ Hristiyanlık uygarlığını değiştirmeye başlamışlardı." Sanat üzerinden açılan yolun devamında gelen ikinci safha ise, düşünce safhası olmuştur. $\mathrm{Bu}$ safha, düşünürlerin çabalarıyla oluşan fikir akımlarının üretilmesiyle ortaya çıkmıştır. "Bu düşünürlerin yazıp çizdiklerinin insanların ruhlarında yaptığı yankılar, Fransız Devrimi'ne sebep oldu”. Inanç üzerinde olan değişim de Reform hareketlerinin ortaya çıkmasına sebep olmuştur. "İnanç, düșünce sanat alanındaki bu değișimlerden sonra Rönesansçı Batı Dünyası kendine özgü yemişini verdi: pozitif bilimin -bir bakıma- karayemişi olan teknik.” Filozoflar, sanatçlar, bilginler ve ekonomi düşünürlerinin dönemi olan "XIX. asırda her yönden Rönesans sonrası Batı uygarlığı en olgun dönemini yaşadı.” Batı'nın bu uygarlık döneminde her alanda zirve noktasına varışı bu yüzyılda gerçekleşmiştir (Karakoç 1987: 81-85; Binici 2012: 98).

Batı'nın Rönesans'la yaptığı atılım sıfırdan başlamış bir adım değildir. Kökü eski Yunan'a dayanan ve insanlığın ortak medeniyetinin külliyatı üzerine eklemlenerek gelişmiş bir medeniyettir. "Pozitif bilimlerde, Rönesans'ın, Endülüs yoluyla temel ilke ve bilgileri, kaynakları İslâm'dan aldığı, bugün sayısız incelemeyle açıkça saptanmıştır. Birçok Batılı bilgin, bu hakikati tespit ve itiraf etmiş bulunuyor." (Karakoç 2000: 51-53).

Rönesans ve reformun özünde, İslâm'dan ve Osmanlıdan alınacak ne varsa alıp onu Batı medeniyetine eklemek ve ona Batı medeniyetinden bir kök bulmak ve bünyesine katmak olduğunu söyleyen Karakoç, Batı'ya ait olan değerleri de iyice abartmaktan ibaret olduğunu söyler. Ancak basskasından aldığını öyle allayıp pullayan Avrupalının bu alıntıları neredeyse hiç belli olmaz (Karakoç, 2012a: 108-109). ${ }^{5}$ Bu konularla ilgili, edebiyattan musikiye, fizikten coğrafyaya kadar pek çok alanlarda örnekler verir.

5 Sezai Karakoç, şiirlerinde de Batı’nın dış görünüşüne aldananları, "gerçeği kabukta bulanlar” eleştirir. Bkz. Turan Karataş, Doğu’nun Yedinci Oğlu: Sezai Karakoç, Kaknüs Yayınları, İstanbul 1998, s. 337-340. Adres Adress 
Karakoç'a göre, Batı ideolojisi "Bilim ve teknolojiyle donanan bir emperyalizm ideolojisi"dir. $\mathrm{Bu}$ düşünce sisteminin temeli "maddi taban olarak kapitalizm, manevi temel olarak Hristiyanlık ruhuna dayanmaktadır.” (Karakoç 2008:136-138).

Karakoç, Batı medeniyetinin "Hakikat medeniyeti" ya da "Vahdaniyet medeniyeti" dediği ana hat medeniyet çizgisiyle ilişkisi üzerinde de durmuştur. Ona göre Batı medeniyeti, "daha başka unsurların karıştığı apayrı bir Hristiyanlık" ve Yahudilik üzerinden Vahdaniyet medeniyetinden unsurlar almıştır. Ancak, Vahdaniyet medeniyetinden aldıklarına, pagan medeniyeti denilen Grek ve Roma medeniyetinden başka unsurlar da katmış, ona özünü ve saflı̆̆ını kaybettirmiştir. Vahdaniyete putperestlik ve çok tanrıcılık çağından katkılar yapmıştır. Rönesans'tan sonra ise bambaşka bir katkı yaparak onu bir nevi "melezleşmiş, hatta soysuzlaşmış bir duruma sokmuştur ve adeta aslıyla ilgisi kalmamıștır." (Karakoç 2003b: 69-78) Batı'yı ilk kritik edenler Müslümanlardır. Bunu dünyanın sulh ve selamete kavuşması, insanın her iki dünyada da mutluğa ulaşması için yapmışlardır (Karakoç 1980: 360-361).

\section{3. İslâm Medeniyeti}

Hz. Âdem'den başlayarak son peygambere kadar inşa edilen hakikat medeniyeti vahiy kaynaklıdır. Ona göre "İslâm medeniyeti Kur'an medeniyetidir." (Karakoç 2005: 76). Dolayısıyla ilahi kaynaklı bu medeniyetin kurucuları da peygamberlerdir. Diğer medeniyetler ise bu medeniyetten ayrılmış, tahrip edilmiş medeniyetlerdir (Karakoç 2005: 16). Tarihi süreç içerisinde oluşan medeniyetlerin bir önceki, sonrakine rehberlik etmiş, kurulan yeni medeniyet onun üzerine inşa edilmiştir. Mezopotamya medeniyeti, Mısır medeniyetine, Mısır medeniyeti Grek medeniyetine, Grek medeniyeti de Roma medeniyetine tesir etmiştir. Rönesans sonrası gelişen Batı medeniyeti, Grek ve Roma medeniyetinin yeniden dirilişidir (Karakoç 1986: 236). Ona göre "İslâm medeniyeti", ya da "Hakikat medeniyeti" yukarda bahsedilen iki medeniyetin dışında onları da içine alan yegâne medeniyettir. Dolayısıyla İslâm, ne Doğu ne de Batı'dır (Karakoç 1975: 399). Karakoç'un "İslâm medeniyeti”, hakikat medeniyeti” gibi adlandırmalarının bir üçüncüsü "Kalp medeniyetidir.” Karakoç’un şüphesiz dinî kaynakları referans alarak belirlediği bu medeniyet tanımı, bütün insanlık için yenidir. "Kalbin kalbe çarpmasından, kalplerin birbirine çarpmasından bir (kalp medeniyeti) doğuyor. İslâm böylece, bir bakıma da, bir kalp medeniyeti demektir.” (Karakoç 2012b: 51). $\mathrm{Bu}$ bağlamda onun medeniyet için kullandı̆̆ medeniyeti"dir (Karakoç 2012a: 64). Temelde ve özde "medeniyet" denilen şeyin "İslâm medeniyeti” olduğunu söyleyen Karakoç, buna Hakikat medeniyeti de denilebileceğini söyler. İslâm medeniyetlerinin reel olarak ortaya çıkmalarının geri planında leitmotif olarak İslâm'ın olduğunu söyleyen Karakoç, bu anlamda "İslâm medeniyetini, medeniyetler medeniyeti" olarak ifade eder. Dolayısıyla vahye dayanan İslâm medeniyeti, filozofların tasnif ettiği, sonlanan ve ölen medeniyetlerden olması da mümkün değildir. İslâm medeniyetinin varyasyonları olarak ortaya çıkan medeniyetler zamanla yerlerini bir sonrakine bırakabileceğine işaret eden Karakoç, bunun bir bayrak yarışı olduğunu, dolayısıyla sonlanma, bitme anlamına gelmeyeceğini söyler. Medeniyetin bozulan, çürüyen, yenilenmeye ihtiyacı olan yönleri olabilir, bazen "fetret dönemine" de girebilir, bu medeniyet kavramının doğasında vardır, ancak buradan yeniden dirilişe geçer (Karakoç 1986:238-239; Karakoç 2012a: 72).

İslâm medeniyetinin kendisini aşan bir medeniyet ve kültür tarafından saf dışı edilemediğine işaret eden Karakoç, bu medeniyetin tarihte var olmuş diğer medeniyetler gibi kitapların ve ilmî çalışmaların bir konusu olamadığını, "bütün cepheleriyle bize nefes aldıran, bizi biz kılan canlı bir medeniyet ve kültür” olduğunu söyler.

İslâm medeniyetinin ırk olarak sadece Arapların ortaya koyduğu bir medeniyet olmadığına vurgu yapan Karakoç, Arap, Acem, Türk ve daha pek çok ırkın İslâm ruhunu "ruhlarına geçirmiş” olarak ortak bir medeniyet inşa ettiklerini söyler (Karakoç 2012a: 104). 
İslâm medeniyeti olgusuna farklı yaklaşan, bu medeniyetin İslâm ve imanla ilgisini azaltmaya ya da aradaki bağa vurgu yapmayanlara karşı da Karakoç’un yaklaşımı oldukça nettir:

“Temel tez, 'medeniyet tezi'dir. Kimse medeniyet tezinin karşısına başka tez çlkarmasın. Çünkü söylediğimiz medeniyet, zaten İslâm ve İman medeniyetidir. İman ve İslâm bu medeniyetin merkezi, çekirdeği, tohumudur. İslâm medeniyeti, iman çekirdeğinin, gökleri kaplayacak dallanma ve budaklanmaya varmış ağacıdır.” (Karakoç 2012a: 72).

İslâm medeniyeti yaralı hâliyle bile Batı medeniyet ve kültürünün insanlı̆̆ı yok etmemesi için direnmektedir. O, medeniyet ve kültürümüzün yüceliğ̈ini anlayabilmek için "dirilişin direnişe dönüşmesi gerektiğg’” çağrısını yapar. Karakoç’un dünya görüşü, hayata bakışı, medeniyet anlayışı, sanat ve edebiyat anlayıșını șekillendiren kavram diriliștir (Emre 2014: 218). Diriliș medeniyetinin isim babası olan Karakoç, bu medeniyete sadece Müslümanların değil, bütün insanlı̆̆ın muhtaç olduğunu söyler. İslâm medeniyeti, insanüstü âlemin de katıldığı, mukaddesler ülkesinin sığınağıdır. İyilik ve huzur medeniyetidir.

Karakoç, İslâm medeniyetinin devam ettiricisi olarak gördüğü Osmanlı Devleti’nin gerilemediğini, yavaş yavaş ilerlediğini, ancak Batı’nın teknik alanda dev adımlar attığ için diğerinin geri kalmış göründüğünü söyler. Sosyal hayatta on dokuzuncu, hatta yirminci yüzylın başlarında Osmanlı'nın medeni bir toplum olduğunu, gayrimüslimlere karşı tavırda bir değișmenin olmadığını ifade eder. Bunun böyle olmasının tek sebebi de İslâm medeniyetidir (Karakoç 2012a: 76-77).

\section{Doğu'nun Sorunları}

Son yıllarda Asya'nın büyük bir değişim geçirdiğine işaret eden Karakoç, Asya'nın geleceğe dönük krizlerinin, korku ve umuttan çok önüne çıkan firsatları değerlendirme noktasında göstereceği tereddütler olacağını söyler. Asya'nın metafizik krizi atlattığını söyler. Son iki yüzyılda büyük sıkıntılar, yokluklar çeken Afrika'nın da geleceğinin umutla dolu olduğunu söyler.

Asya uzun çağlar boyunca oluşan geleneğine bağlı olarak yavaş yavaş gelişir. "Umutta da yavaștır, korkuda da.” (Karakoç 2012a: 79). Doğu (en saf hâliyle Hint ve Çin) için ideal olan eskidir, mükemmellik eskiye yaklaşıldığı oranda gerçekleşir.

Doğu'nun temel çıkmazlarından birinin Batı’yı mutlak üstün olarak görmesidir. Dolayısıyla Doğu'da görülen siyasio, ahlâki ve ictimai buhranla Batı medeniyetinin yakın ilişkisi vardır. Oralardan ithal edilen fikirlerle bu olușmuștur. "Hürriyet" bunlardan birisidir (Karakoç 1998: 59). Son dönemde İslâm ülkelerinde Batı'nın mutlak üstün kabul edilme düşüncesinden, yani "romantik" anlayışından çıkılmaya başladığına işaret eden Karakoç, bu geçiş dönemini birkaç madde altında toplar.

Batı'da ortaya çıkan buhran ve dünya savaşlarında Batı'nın kendi içinde birbirini yok etmeye yönelmesi Doğu'nun Batı'ya olan “romantizm”inden sıyrılmasına vesile olmuștur. Batı'nın düşünce, hayat tarzı, dünya görüşünde ve siyasi konularda iki kampa bölünmesi İslâm ülkelerindeki yarı aydın denilebilecek insanları bu iki kamptan birisini seçmeye zorlamıştır. $\mathrm{Bu}$ da bir kritik etmeyi doğurmuştur. Batılı gibi olma özentisinin ortaya çıkardığı genç nesil, yine oradan gelen kısmi ölçüler çerçevesinde sıkıntıdan, sıkılmaktan bahsetmeye başlamışlardır. En önemlisi ise İslâm ülkelerindeki gerçek aydınlarının Batı'ya gerçek anlamda eleştirel bakmaları bu uyanışın başlamasında en önemli amil olmuştur (Karakoç 1997a: 102-103).

\section{Batı'nın Çıkmazı/Bunalımı}

On yedinci yüzyılda Rönesans'la başlayan ve maddeye hâkim olan Batı'nın her șeyi akılla ve bilimle çözme düşüncesi beraberinde belli çıkmazları da getirmiştir. Dolayısıyla Batı medeniyeti maddiyat bakımından terakki ederken, metafizik olarak insanın ruhuna 
dokunamadığı için onu mutlu edememiştir. Çünkü "akıl şüpheden yola çıkar, inançsa şüphesizlikten.” (Karakoç 1969: 405). Aklın egemenliğini kuran Batı'da inanç, onun kölesi olmaya dayanamadığı için yıkılmıştır. Batıl inançların, içgüdü yanılmalarının "sara birsamlarının heyecanını yaşayan” Batı, sonunda aklın kölesi olmuştur.

Karakoç, Batı'nın ve dolayısıyla dünyanın bugün içinde bulunduğu durumun geçici bir bunalım durumu olmadığını söyler. Hatta o bunalım kelimesinin bile durumu izah edemeyeceğini ifade eder. Batı'nın bunalımın bir çeşit "varoluş bunalımı" olarak nitelendirir. Kendi sanat adamı, şair ve düşünürlerinin bu bunalıma bir çözüm getiremedikleri gibi, yüzyıllardır kendilerinin dışında olan Avrupa, Asya ve Afrika'nın insan kitlelerini ezdikleri için oralardan da kendilerine uzanacak bir el bırakmamışlardır. Bozuluşun Rönesans'tan bașladığına işaret eden Karakoç, yeni bir olușta bulunması gereken orijinal bir özün bulunmaması ve İslâm'ı gereği gibi değerlendirememesi gibi yönleriyle Rönesans'ın eksikliklerini ortaya koyar. Nitekim metafizik temelleri zayıf olan bu düşüncenin uzun ömürlü olması da mümkün değildir. Nitekim Avrupa yirminci yüzyılda iki büyük savaşla kendini içten içe sarsınca gerçekle yüzleşmek durumunda kalmış, kendi dışında olanlar da kendilerini bulma yolunda araștırmaya yönelmişlerdir. Karakoç, Batı sorununun siyasi ya da ekonomik sebeplerle izah edilemeyeceğini ifade ettikten sonra, "Rönesans'tan gelip bugüne kadar sürüklenmiş bulunan, yani başarıların maskesi arkasında saklı duran metafizik problem, uygarlık problemi olarak ortaya çıkmış bulunuyor” değerlendirmesinde bulunur (Karakoç 1987: 13-17).

Karakoç, başka yazılarında da aynı hususa dikkat çekerek, Batı medeniyetinin temel problemini medeniyetin çıkış kaynağı olan Rönesans’a dayandırmaktadır. Çünkü bir medeniyet ya da devletin ömrü doğuş ve çıkışında gizlidir. O oluşum "dünyaya gelirken beraberinde yaşama gücünü, dayanma ve uyum sağlama özelliğini de beraberinde getiriyor.” (Karakoç 1999:248).

Son beş yüzylllı dönemde insanlığı etkisi altına alan Rönesans düşüncesi üzerine kurulmuş olan Batı medeniyeti, insanlığın bugünkü sorunlarına cevap veremeyecek duruma gelmiştir. Dolayısıyla insanlık uyanmaya başlamış ve Batı'dan hesap sormanın yollarını arar hale gelmiştir (Karakoç 1987: 18-19). Bunun temelinde de metafizik eksikliği yer alır (Binici 2012: 108).

Batı medeniyetinde Eski Yunan'da site dışındakiler yabancı sayılır, Yunanlı olmayana insan gözüyle bakılmazdı. Romalı, kendisini öbür insanlardan ayırmayı bir hukuk kuralı saymıştır. Nitekim onların Hristiyanlıkta en çok kabul etmedikleri nokta "bir köle ile bir Romanlının kardeş sayılması"dır. Eski Yunan ve Roma'nın yeniden doğuşu olan Rönesans sonrası Batı medeniyetinde de bu düşünce şuur altında hep devam etmiştir. Dolayısıyla Amerika'da yerlilere yapılan zulümler, Avrupa'nın Afrika'da Asya'da yaptıkları hep buna dayanmaktadır. Karakoç'un Avrupa için yaptığı şu tespit dikkat çekicidir: "Avrupa ne zaman dirilmişse insanlık o vakit bunalmış ve ezilmiş, ne zaman bir iç kavgaya sahne olmuşsa insanlık bir parça rahat nefes almıştır." (Karakoç 1996: 51).

Batı'ya ve Batı medeniyetine karşı insanlığın olumsuz bakması, düşmanca yaklaşmasının altında Batı'nın kendinden olmayanları ezmesi, sömürmesi yatmaktadır. Batı'ya karşı alınan tavrı kölelerin Roma'ya isyanına benzeten Karakoç, Batı'ya özenmenin de tersten okumayla bir çeşit onun silahıyla silahlanma olarak görür (Karakoç 1987: 23-24).

Karakoç Avrupa'nın ya da Avrupa kültürünün yirminci yüzyılda kısa aralıklarla yaşadığı iki büyük cihan savaşılla büyük bir korkuyu en çok hissedecek olan medeniyet olduğunu ifade eder. Dolayısıyla gelecek zamanda en büyük korkuyu çekecek olan Avrupa'dır. Henüz komünizmin yıkılmadığı ve etkili olduğu bir dönemde Avrupa'dan ihraç edilen bu fikrin Batı'da korkulacak bir tarafının olmadığını, ancak faşizm korkusunun Batı'nın en büyük korkusu olabileceğini söyler. "Avrupa buhranı daha derinlerdedir" diyen Karakoç, zaman içinde ortaya çıkan kişiler üzerinden Avrupa'nın uzun vadede yürümeyeceğini söyler. Bütün Avrupa'nın Amerika'yı, kendi kültüründen çıkmış olsa da, İncil'deki kıssanın benzeri olarak, 
“aile yuvasını terk etmiş, sonradan da elde ettiği tarihsiz ve ruhsuz imkânlarla uzaktan hegemonyası altına almak isteyen bir "müsrif oğul” olarak gördüğüne işaret eder. Kendi derinliğinden dolayı, komünizme, faşizme ve Amerika'ya farklı bakan Avrupa yeni bir “doktrinin” özlemini çekmektedir (Karakoç 2012a: 81-83).

On dokuzuncu yüzyılda en yoğun düşünce ve ruh dünyasını yaşayan, en önemli sanatçı, filozof, ilim adamı, ideolog yetiştiren Batı bir durgunluk devresine girmiştir. Dolayısıyla bir korkuya kapılan Avrupa için tek devlet, tek Avrupa gibi girişimlerin kaynağı bu panik ve korkudandır. Ancak tarihte Kartaca, Mısır, Yunan ve Roma medeniyetinin başına gelen Avrupa medeniyetinin de alın yazısıdır (Karakoç 1996: 126).

Batı medeniyetini "tehlike medeniyeti" olarak nitelendiren Karakoç, tarih boyunca bir medeniyet bir başka medeniyet tarafından ortadan kaldırılmışken, günümüzde ilk defa tehlike üzerine inşa edildiğini ifade ettiği Batı medeniyetinin kendi kendisini ortadan kaldırmaya çalıştığını söyler. Her medeniyette tehlike dışta olduğu hâlde Batı medeniyetinde tehlike içerdedir. Tehlike, Batı medeniyeti için bir yaşayış sebebi, adeta bir çeşit ruhi yiyeceğidir. Cihan harpleri de bu medeniyetin eseridir. Topyekûn savunma, topyekûn savaș gibi ifadeler Batı üzerinden gelmiştir. Dolayısıyla "Batı medeniyetinin ana vasfı budur: Tehlike” (Karakoç, 1998: 56-58).

Batı'nın en büyük dramı, kendisi dışında kalan insanlığa kendisini hiçbir zaman sevdirememiş olmasıdır. Dolayısıyla kendisinden önce gelmiş diğer medeniyetlerden temel farkı da bu "antipati ve cevapsızlık"tır. Hâlbuki bu medeniyetten önceki Roma medeniyeti Yunan medeniyetiyle kaynaşmış, İslâm ölü Yunan medeniyetinden kendisi için faydalı olanları ayıklayarak kendi bünyesine katmıştır. Rönesans sonrası Avrupa ise, İslâm medeniyetini yakıp yıkmaya, inkâr etme yoluna gitmiştir. Endülüs medeniyetinin başına gelenler bunun canlı örneğidir. Dolayısıyla Batı medeniyetinin Asya'da ve Afrika'da tepki görmesinin sebebi bu bakış açısından kaynaklanmaktadır (Karakoç 1995: 9-10).

Irak Savaşı vesilesiyle "Mektup" başlıklı yazısında "Batı'da sesleneceğimiz bir kulak yoktur. Mektup yazacağımız bir sanatçı, şair, filozof bir kişi mevcut değildir aralarında. Artık etkin filozoflar, şairler, sanatçllar dönemini de kapadı Batı.” der (Karakoç 2012a: 57). Ona göre, Batı'nın problemi sadece siyasi değildir. Ahlâki bakımdan da özellikle genç nesil arasında büyük bir çöküş vardır (Karakoç 2003a: 43).

\section{Sonuç}

Son yarım asrın büyük sanatkâr, şair ve fikir adamı Sezai Karakoç'un temel kavramlarından birisi medeniyettir. Türk düşünce tarihinde genel olarak yapılan Doğu-Batı medeniyeti gibi sinıflandırmalar yerine, o tek bir medeniyet olduğunu, bunun da "İslâm medeniyeti", diğer ifadelerle "Hakikat medeniyeti", "Vahiy medeniyeti," Kalp medeniyeti" olduğunu söyler. Ona göre diğer medeniyetler de buradan çıkmış medeniyetlerdir. Karakoç'a göre Doğu medeniyeti, İslâm medeniyetinden tamamen farklı eski Hint ve Çin medeniyeti için kullanılır.

Batı medeniyeti ise, kökünü eski Yunan ve Grek Kültüründen alan Roma'da neşvünema bulan bir medeniyettir. Rönesans'la yeniden yorumlanan bu medeniyetin temeli akla dayanmaktadır. Maddeyle her şeyi çözeceğini düşünen bu medeniyet anlayışı bir iki asır sonra insanı mutlu edememiş, felaketlere sebep olmuştur. İslâm medeniyetinin zayıflamasıyla özellikle on sekizinci ve on dokuzuncu yüzyılda Batı medeniyeti hayranlıkla takip edilmiş, örnek alınmıştır. Osmanlı aydını, birkaç istisna dışında bu medeniyete büyük hayranlık duymuş, bunun eksik, aksayan yanlarının olabileceğini hiç düşünmemiştir. Batı medeniyetinin sorgulanmaya başlanması ya da ilk şüphenin oluşması iki dünya savaşından sonradır. Kendi içinde büyük felaketlere sebep olan bu medeniyetin insanı huzurlu edemediği/edemeyeceği, maddeyle her şeyi çözemeyeceği anlaşılmıştır.

Medeniyetler tarih içinde birbirinden şu ya da bu şekilde etkilenmişlerdir. İslâm medeniyeti dışındaki medeniyetler birbirinin yerine geçen bir medeniyetin cüzleridirler. Ancak "İslâm 
medeniyeti" veyahut "Diriliş medeniyeti” denilen ve kökü vahye dayanan bu medeniyet, ilk insan ve ilk peygamberden son peygambere kadar kesintisiz devam eden, birbirini tamamlayan bir medeniyettir. İnsanı merkeze alan, ilahi bir kudretten doğan bu medeniyet insanlığa huzur ve barışı getirmiştir. Zaman içinde ufak iniş çıkışlar olsa da bugün insanlığı huzura kavuşturacak tek medeniyettir.

\section{Kaynakça}

Ayverdi, İlhan (2005), Misalli Büyük Türkçe Sözlük, C. II-III, İstanbul: Kubbealtı.

Baş, Münire Kevser (2008), Diriliş Taşları Sezai Karakoç’un Düşünce Ve Sanatında Temel Kavramlar, Ankara: Lotus.

Baykara, Tuncer (1982), “Bir Kelime - Istılah ve Zihniyet Olarak 'Medeniyetin Türkiye'ye Girişi”, Fikir ve Sanatta Hareket, C. VII. Devre, S. 25, Mart 1982, s. 7-11).

Baykara, Tuncer (2007), Osmanlılarda Medeniyet Kavramı, İstanbul: IQ Kültür Sanat.

Bayraktar, Osman (2008), “Sezai Karakoç’ta Batıya Bakıș”, Şair ve Düşünür Sezai Karakoç Sempozyumu, (ed. Saadettin Acar-Vahdettin Işık) İstanbul: Fatih Belediyesi Yayınları, s. 283-294.

Bilge, Muhittin (2006), “Diriliş Düşüncesinin Teklifleri ve Retleri”, Kahraman Maraş’ta Sezai Karakoç’la Kırk Saat, Kahraman Maraş: Kahraman Maraş Belediyesi, s. 75-82.

Binici, Volkan (2012), Sezai Karakoç'ta Medeniyet Kavramı, Fatih Üniversitesi Sosyal Bilimler Enstitüsü (Yayımlanmamış Yüksek Lisans Tezi), İstanbul.

Emre, İsmet (2014), “Sezai Karakoç’un Ontolojik Anahtarı: Diriliş”, Sezai Karakoç Sempozyumu Bildirileri, Ankara: s. 213-223

Görgün, Tahsin (2000), "Medeniyet (Modern Tartışmalar)”, Türkiye Diyanet Vakfi İslâm Ansiklopedisi (DIA), İstanbul: TDV Yayınları, C. XXVIII, s. 298.

Güler, Ruhi (2006), “Tanzimat’tan II. Meşrutiyete Medeniyet Kavramının Evrimi”, MÜ SBE (Yayınlanmamış Doktora Tezi), İstanbul.

Kaplan, Yusuf (2008), "Bütün Zamanların Çocuğu ve Medeniyet Fikriyatının Öncüsü Düşünür: Sezai Karakoç”, Şair ve Düşünür Sezai Karakoç Sempozyumu, (ed. Saadettin Acar-Vahdettin Işık), İstanbul: Fatih Belediyesi Yayınları, s.211-233.

Karaca, Alaattin (2015), "Sezai Karakoç'un Şiirlerinde Şehir, Coğrafya ve Medeniyet”, Medeniyetin Burçları Sezai Karakoç Kitabı (Ed. Ali Dursun), Kayseri, s.392-404.

Karakoç, Sezai (1980), Sütun, İstanbul: Diriliş.

Karakoç, Sezai (1975), Sütun I, İstanbul: Diriliş.

Karakoç, Sezai (1969), Sütun II, İstanbul: Diriliş.

Karakoç, Sezai (1977), Çağ ve İlham I, İstanbul: Diriliş.

Karakoç, Sezai (1986), Gün Saati, İstanbul: Diriliş.

Karakoç, Sezai (1987), İnsanlığın Dirilişi, İstanbul: Diriliş.

Karakoç, Sezai (1995), İslâmın Dirilişi, İstanbul: Diriliş. 
Karakoç, Sezai (1996), Günlük Yazılar III, Sur, İstanbul: Diriliş.

Karakoç, Sezai (1997a), Günlük Yazılar I Farklar, İstanbul: Diriliş.

Karakoç, Sezai (1997b), İslâm, İstanbul: Diriliş.

Karakoç, Sezai (1998), Diriliş Çerçevesinde, İstanbul: Diriliş.

Karakoç, Sezai (200o), Edebiyat Yazıları 3:Eğik Ehramlar, İstanbul: Diriliş.

Karakoç, Sezai (2003a), Çıkış Yolu 1: Ülkemizin Geleceği İki Konferans, İstanbul: Diriliş.

Karakoç, Sezai (2003b), Çıkışı Yolu 2: Medeniyetimizin Dirilişi Dört Konferans: İstanbul: Diriliş.

Karakoç, Sezai (2005), Düşünceler 1: Kavramlar, İstanbul: Diriliş.

Karakoç, Sezai (2008), Fizik Ötesi Açısından Ufuklar ve Daha Ötesi 2 Diriliş Şoku, İstanbul: Diriliş.

Karakoç, Sezai (2012a), Fizik Ötesi Açısından Ufuklar ve Daha Ötesi I Perde Yıkıldığı An, İstanbul: Diriliş.

Karakoç, Sezai (2012b), Kıyamet Aşısı, İstanbul: Diriliş.

Karataş, Turan (1998), Doğu’nun Yedinci Oğlu: Sezai Karakoç, İstanbul: Kaknüs.

Kutluer, İlhan (2000), "Medeniyet”, Türkiye Diyanet Vakfi İslâm Ansiklopedisi (DİA), İstanbul: TDV, C.28, s. 296-297.

Meriç, Cemil (1983), “Batılaşma”, CDTA, C. I, İstanbul: İletişim.

Okay, Orhan (1991), Batı Medeniyeti Karşısında Ahmed Midhat Efendi, Ankara: MEB.

Süreya, Cemal (2004), 99 Yüz - İzdüşümler/Söz Senaryosu, İstanbul: Adam, s.278-279.

Tanpınar, Ahmet Hamdi (2007), XIX. Asır Türk Edebiyatı, İstanbul: Yapı Kredi.

Uçman, Abdullah (2014), "Batı, Batı Dedikleri”, Hece Batı Medeniyeti Özel Sayısı, S.210-212 Haziran-Temmuz Ağustos, 2014, s. 617-620.

Uludă̆, Süleyman (2003), “Din ve Medeniyet”, Köprü, S. 81, İstanbul, s.22-30. 